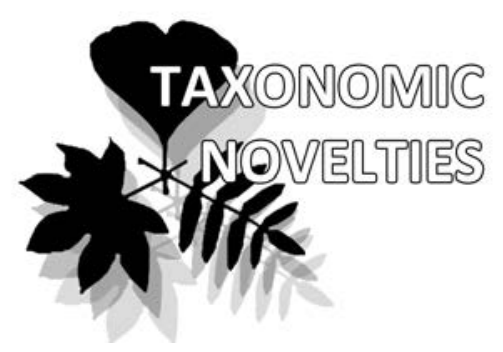

\title{
Two new species of Gymnomitriaceae (Marchantiophyta) in the North Pacific
}

Yuriy S. Mamontov*1,3

e-mail: yur-mamontov@yandex.ru

Anna A. Vilnet ${ }^{2}$

e-mail: anya_v@list.ru

Nadezhda A. Konstantinova ${ }^{2}$

e-mail: nadya50@list.ru

Vadim A. Bakalin

e-mail:vabakalin@gmail.com

${ }^{1}$ Botanical Garden-Institute FEB RAS

Vladivostok, Russia

2 Polar-Alpine Botanical Garden-Institute, Kola Science Centre RAS, Kirovsk, Russia

${ }^{3}$ Tsitsin Main Botanical Garden RAS, Moscow, Russia

* corresponding author

Manuscript received: 06.12 .2018

Review completed: 05.04.2019

Accepted for publication: 10.04.2019

Published online: 14.04.2019

\begin{abstract}
A B S T R A C T
Two new liverwort species, Gymnomitrion kamchaticum sp. nov. and Marsupella aleutica sp. nov., are described based on integrative taxonomical approach derived from morphology, phytogeography and sequence data. Gymnomitrion kamchaticum is morphologically most similar to Gymnomitrion brevissimum, G. mucronulatum and G. pacifcum, but differs from them by leaf insertion, shape of leaves and leaf cells. Marsupella aleutica is morphologically somewhat similar to the Holarctic M. emarginata s.l., $M$. funckii, M. sprucei, $M$. ustulata and the East Asian M. minutissima and M. pseudofunckii, but differs in leaf shape and occasional presence of a tooth at antical leaf base.

K e y w o r d s : Hepaticae, taxonomy, new species, Aleutians, Kamchatka, ITS1-2 nrD$\mathrm{NA}, \operatorname{trn} \mathrm{L}-\mathrm{F} c p \mathrm{DNA}$
\end{abstract}

\section{P E 3 Ю M E}

Мамонтов Ю.С., Вильнет А.А., Константинова Н.А., Бакалин В.А. Ава новых вида Gymnomitriaceae (Marchantiophyta) из Северной Пацифики. Ава новых Аля науки виАа, Gymnomitrion kamchaticum sp. nov. и Marsupella aleutica sp. nov. выявлены и описаны на основе использования данных морфологии, молекулярной филогенетики и фитогеографии. Gymnomitrion kamchaticum внешне наибоолее сходен с Gymnomitrion brevissimum, G. mucronulatum and G. pacificum, однако отличается от этих видов по признакам формы и прикрепления мистьев, а также по характеру края миста и краевых клеток. ВиА Marsupella aleutica Отчасти сходен с голарктическими вилами M. emarginata s.l., M. funckii, M. sprucei, M. ustulata и восточноазиатскими M. minutissima и M. pseudo funckii, однако отличается от них формой мистьев, а также развитием зубца в основании дорсальной части основания Аиста.

КАючевые слова: печеночники, систематика, новые виды, Алеутские острова, Камчатка, ITS1-2 ядАHK, trnL-F $x n \Delta \mathrm{HK}$
The species of the leafy liverwort family Gymnomitriaceae (Marchantiophyta) particularly those of the largest genera of the family, Gymnomitrion Corda and Marsupella Dumort. are mainly restricted to areas difficult to access in upper belts of mountains as well as to polar regions (Váňa et al. 2010: 10). As a result the diversity and distribution of species in these genera are still insufficiently known (Váňa et al. 2010: fig. 4). The first phylogenetic reconstruction of Gymnomitriaceae by Vilnet et al. (2007) inferred from ITS1-2 nrDNA and trnL-F cpDNA indicates that Gymnomitrion and Marsupella in the traditional meaning are polyphyletic. This study involves analyses of 17 taxa from three of nine genera in this family and is concentrated on the phylogeny of the two largest genera mentioned above. Recently the affinity of genera within the family Gymnomitriaceae were established in molecularphylogenetic studies of the suborder Jungermanniineae by Vilnet et al. (2010) and Shaw et al. (2015). Recently, in the frame of revision of Gymnomitrion and Marsupella in Europe, Asia and North America efforts are under way to the special estimate of the family diversity under integrative taxonomy approaches. The morphological examination of specimens from the Yunnan Province, China, resulted in the description of a new species Gymnomitrion fissum Mamontov et Potemkin
(Potemkin et al. 2017) and by exploring DNA data the resurrection of Marsupella parvitexta Steph. as a semi-cryptic segregate of Gymnomitrion commutatum (Limpr.) Schiffn. was provided (Mamontov et al. 2018).

The current study aims to describe new species of Gymnomitrion and Marsupella that were found in collections from Kamchatka and the Aleutians during a pilot study of Gymnomitriaceae phylogeny based on integrative taxonomical approach.

\section{MATERIAL AND METHODS}

The specimens were examined and photographed using a Leitz Wetzlar Orthoplan light microscope and an Olympus SZX16 stereomicroscope both equipped with digital cameras. The plant habit and some morphological details not visible enough on photo were drawn. The holotype of Gymnomitrion mucronulatum N.Kitag. (8 VIII 1952 D. Shimizu, No. 56660, NICH) was studied to provide its distinctions from the new Gymnomitrion species described here. To prepare the key for Gymnomitrion species the specimens of G. pacificum Grolle and G. brevissimum (Dumort.) Warnst. housed in KPABG, VBGI and MO were additionally investigated and its descriptions in Schuster (1974) and Dam- 
sholt (2002) were used. The key distinctions of G. mucrophorum R.M. Schust. are provided in the key according to its description in Schuster (1995). The key for Marsupella species is based on the studied type specimens of $M$. aleutica, the specimens of $M$. emarginata s.l., M. funckii (F. Weber \& D. Mohr) Dumort. and M. sprucei (Limpr.) Bernet housed in KPABG, VBGI and MO, and the descriptions of these species in Schuster (1974) and Damsholt (2002). The key distinction of $M$. minutissima N. Kitag., M. pseudofunckil S. Hatt and the East Asian taxa of M. emarginata s.l. follow its descriptions in Kitagawa (1963).

\section{Taxa sampling}

To test phylogenetic affinity of poorly known and presumably new taxa from the family Gymnomitriaceae the newly sequenced ITS1-2 nrDNA and trnL-F cpDNA loci from 10 specimens of Gymnomitrion species and a single specimen of Marsupella from geographically separate regions (China, Mexico, the Russian Far East and USA) were included to the dataset from Mamontov et al. (2018). This dataset was changed by reduction of multiply sampled species and inclusion of Cryptocoleopsis imbricata Amakawa and Poeltia campylata Grolle. In total, the alignment produced here includes nucleotide sequences of 33 taxa and 50 specimens, where DNA-data for 35 specimens were taken from our previous studies (Yatsentyuk et al. 2004, Vilnet et al. 2010, Mamontov et al. 2018) and trnL-F nucleotide sequences were downloaded from GenBank for four Gymnomitrion species. The ingroup genera Gymnomitrion and Marsupella are represented by 26 taxa (including new and morphologically indeterminate) which is ca $45 \%$ of the worldwide known species of Gymnomitrion and Marsupella (Söderström et al. 2016). Eremonotus myriocarpus (Carrington) Pearson was chosen as outgroup taxon according to the phylogeny obtained in Vilnet et al. (2010). GenBank accession numbers and voucher details are listed in Appendix 1.

\section{DNA isolation, PCR amplification and DNA sequencing}

DNA was extracted from dried liverwort tissue using the NucleoSpin Plant Kit (Macherey-Nagel, Germany). Amplification and sequencing were performed using primers given by White et al. (1990) for ITS1-2, Taberlet et al. (1991) for $t r n$ L-F. PCR was carried out in $20 \mu$ volumes with the following amplification cycles: $3 \mathrm{~min}$ at $94^{\circ} \mathrm{C}, 30$ cycles $(30 \mathrm{~s}$ $94^{\circ} \mathrm{C}, 40 \mathrm{~s} 56^{\circ} \mathrm{C}, 60 \mathrm{~s} 72^{\circ} \mathrm{C}$ ) and 2 min of final extension time at $72^{\circ} \mathrm{C}$. Amplified fragments were visualized on $1 \%$ agarose TAE gels by EthBr staining, purified using the GFX PCR DNA and Gel Band Purification Kit (Amersham Biosciences, USA), and then used as a template in sequencing reactions with the ABI Prism BigDye Terminator Cycle Sequencing Ready Reaction Kit (Applied Biosystems, USA) following the standard protocol provided for 3100 Avant Genetic Analyzer (Applied Biosystems, USA).

\section{Phylogenetic analyses}

Two nucleotide alignments, ITS1-2 and trnL-F, were obtained with the ClustalW option and then manually corrected in BioEdit 7.0.1 (Hall 1999). The topologies of the strictconsensus trees of non-parametric bootstrap analyses were congruent between ITS1-2 and trnL-F and consequently both datasets were combined. All positions of the final alignment were included in the phylogenetic analysis; parts of sequences that were lacking and unsequenced loci were coded as missing.

The combined alignment of ITS1-2+trnL-F was analyzed using three analytical procedures: the maximum parsimony method (MP) using the TNT 1.5 (Goloboff \& Catalano 2016), the maximum likelihood method (ML) using PhyML v. 3.0 (Guindon et al. 2010) and Bayesian reconstruction with MrBayes v. 3.2.1 (Ronquist et al. 2012).

The MP analysis involved a New Technology Search with a search for the minimum-length tree by five reiterations and 1000 bootstrap resamplings; the default settings were used for other parameters, indels were taken into account by a modified complex coding algorithm in SeqState (Müller 2005).

The program ModelGenerator (Keane et al. 2004) determined that the GTR $+\mathrm{I}+\Gamma$ model was the best-fit evolutionary model of nucleotide substitutions for the produced alignment. In the ML analysis the $G T R+I+\Gamma$ model was used and the rate of heterogeneity among sites was modelled using a gamma distribution with four rate categories. Bootstrap support (BS) for individual nodes was assessed using a resampling procedure with 500 replicates. According to the stopping frequency criterion (FC) for bootstrapping procedure (Pattengale et al. 2010) even 200 replicates were enough for our dataset to reach BS convergence with Pearson average $\varrho 100=0.994324$ realized in RAxML v. 7.2.6 (Stamatakis 2006).

For the Bayesian analysis each partition of the combined alignment (ITS1-2, trnL-F) was separately assigned the GTR $+\mathrm{I}+\Gamma$ model, gamma distributions were approximated using four rate categories. Two independent runs of the Metropolis-coupled MCMC were used to sample parameter values in proportion to their posterior probability. Each run included three heated chains and one unheated, and two starting trees were chosen randomly. Chains were run for one million generations and trees were sampled every 10th generation. The software tool Tracer (Rambaut \& Drummond 2007) revealed effective sample size (ESS) as 2925.7033 and auto-correlation time (ACT) as 615.2435 for our data. As determined by Tracer, the first 10000 trees in each run were discarded as burn-in. Thereafter 90000 trees were sampled from each run. The average standard deviation of split frequencies between two runs was 0.004825 . Bayesian posterior probabilities were calculated from trees sampled after burn-in.

The infrageneric and infraspecific variability of each DNA locus was evaluated as value of p-distances between specimens and species (Table 1,2), as calculated in Mega 5.1 (Tamura et al. 2011) using the pairwise deletion option for counting gaps.

\section{RES U LTS}

\section{Phylogenetic reconstructions}

ITS1-2 sequences were newly obtained for 11 specimens and trn L-F for 10 specimens. The combined alignment of the two genomic regions contains 1377 character 


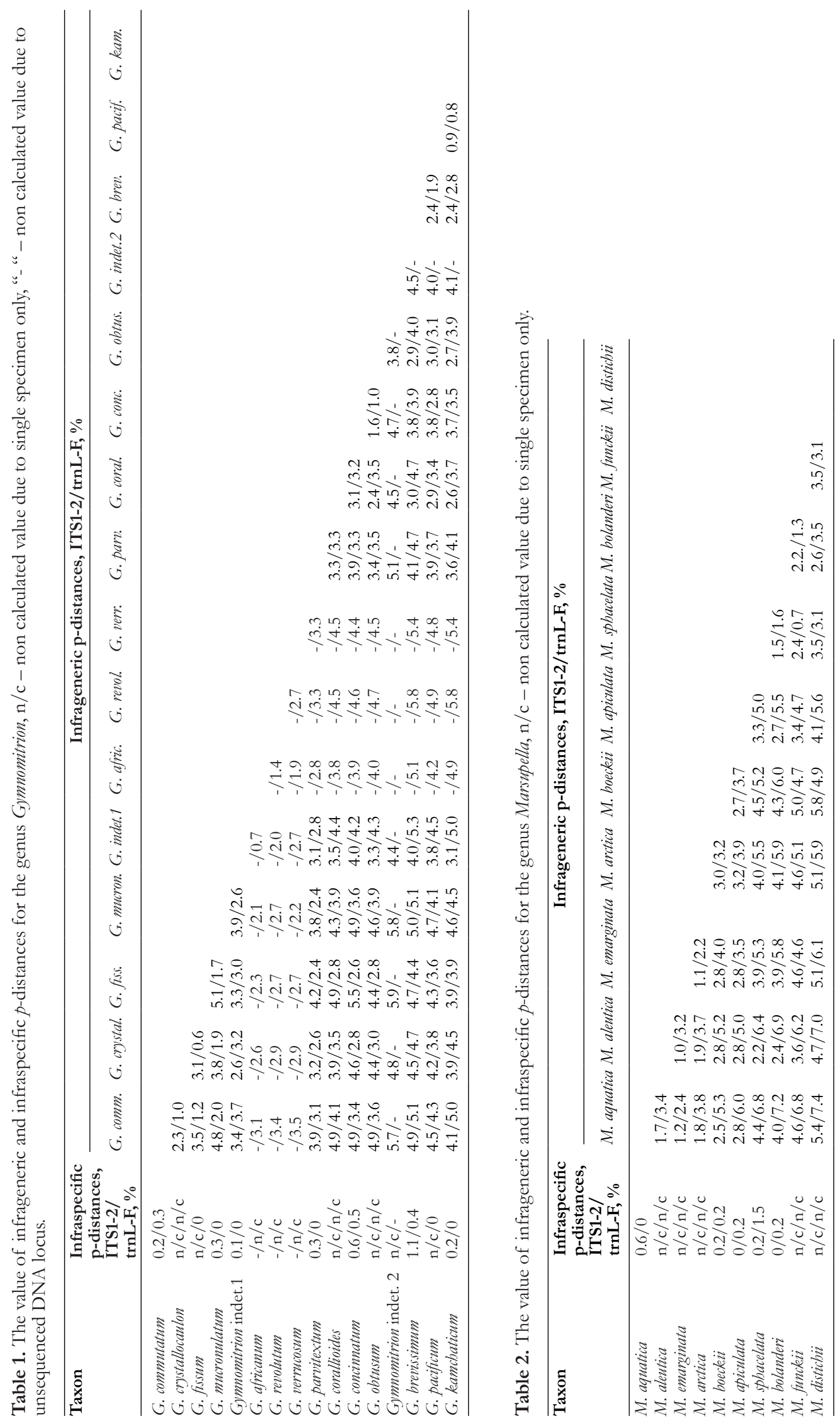


sites, among them 897 positions belong to ITS1-2 and 480 - to trnL-F. The number of constant positions in ITS1-2 is $605(67.45 \%)$ and in trnL-F is $313(65.21 \%)$, variable $-273(30.43 \%)$ and $155(32.29 \%)$, parsimoniously informative $-170(18.95 \%)$ and $98(20.42 \%)$, respectively. In the combined ITS1-2 + trnL-F alignment 918 (66.67\%) positions are constant, $428(31.08 \%)$ are variable and 268 $(19.46 \%)$ are parsimoniously informative.

The MP analysis yielded eight equally parsimonious trees with a length of 1471 steps, with CI $=0.636891$ and $\mathrm{RI}=0.800510$ calculated in Mega 5.1. The ML calculation resulted in a single tree, the arithmetic mean of Log likelihood was -6735.201952. Arithmetic means of Log likelihoods in Bayesian analysis for each sampling run were -6598.56 and -6595.61 . The tree topologies achieved by the three methods are quite similar and does not contradict the previously published tree (Mamontov et al. 2018). Thus, we provide the ML tree with an indication of bootstrap support values (BS) calculated in the MP and ML analyses and Bayesian posterior probabilities (PP) (Fig. 1).

Three main clades can be distinguished in the tree topologies. The species attributed to the genus Gymnomitrion composes the first clade with BS $=100 \%$ in MP, BS $=74 \%$ in $\mathrm{ML}$ and $\mathrm{PP}=1.00 \%$ in $\mathrm{BA}$ (or 100/74/1.00). The second clade unites species from the genus Marsupella (66/62/1.00) and Poeltia campylata, which sister relation to Marsupella is not supported. The third clade includes the sister related Prasanthus suecicus (Gottsche) Lindb. and Cryptocoleopsis imbricata $(68 / 89 / 1.00)$. At the moment the species sampling (45\% of the worldwide known species) still is insufficient to discuss the phylogeny of Gymnomitriaceae, but the presented data supports the distinction of some poorly known, recently described taxa.

The Himalayan Marsupella crystallocaulon Grolle (1966), transferred to Apomarsupella R.M. Schust. by Váňa (1999) and then to Gymnomitrion by Shaw et al. (2015), is here found related to Gymnomitrion commutatum by molecular data $(65 / 86 / 0.99)$. Thus, the treatment of this species as a member of Gymnomitrion is supported.

The specimen of the recently described Gymnomitrion fissum from China (Potemkin et al. 2017) is placed in a sister relation (90/98/0.99) to a Chinese specimen previously published as G. commutatum in Shaw et al. (2015) and separated from the clade with multiple samples of $G$. commutatum in Mamontov et al. (2018). This clade is related to G. crystallocaulon (Grolle) Váňa, Crand.-Stotl. \& Stotler and G. commutatum (79/97/1.00). The trnL-F sequences of both $G$. fissum specimens does not provide variability, but is distinct from G. crystallocaulon by $0.6 \%$ and $G$. commutatum by $1.2 \%$, whereas in ITS1-2 by $3.1 \%$ and $3.5 \%$ respectively (Table 1 ). The nucleotide sequence data obtained here once again confirm the description of G. fissum as a distinct species.

Two newly sequenced specimens of Gymnomitrion from Kamchatka Peninsula (96/9/1.00) are found in a sister relation (99/98/1.00) to G. pacificum from Alaska and Bering Island (94/78/-). Both samples from Kamchatka reveal variability only in ITS1-2 $(0.2 \%)$, whereas $\operatorname{trn} \mathrm{L}-\mathrm{F}$ are stable like that in both $G$. pacificum specimens. The sequence divergences of an unknown taxon and G. pacificum are $0.9 \%$ in
ITS1-2 and $0.8 \%$ in $t r n$ L-F (Table 1). The level of ITS1-2 sequence divergence in the discussed species pair is lower than in $G$. crystallocaulon-G. fissum-G. commutatum with the same level of $\mathrm{p}$-distances in trn $\mathrm{L}-\mathrm{F}$. Taking the morphological differences into account (see below) together with the level of genetic distances, the studied specimens from Kamchatka are distinguished here as a new species Gymnomitrion kamchaticum sp. nov.

The specimens marked on Fig. 1 as "Gymnomitrion indet. 1 " and "Gymnomitrion indet. 2" need special further study.

The specimen of Marsupella from the Aleutian Is, Alaska (UBC) was found in a sister relation (84/53/0.78) to the clade combined by two specimens of $M$. aquatica (Lindenb.) Schiffn. (98/100/1.00). The p-distance between the Aleutian specimen and $M$. aquatica is $1.7 \%$ by ITS1-2 and $3.4 \%$ by $t r n$ L-F. This specimen differs distinctly in appearance from $M$. aquatica and other species of the genus. The reliable molecular and morphological differences allow us to describe a new species - Marsupella aleutica sp. nov.

Gymnomitrion kamchaticum Mamontov, Vilnet et Konstant. sp. nov. Fig. 2, 3, 6: A, C, E, F

Description. Plants yellowish, golden or reddish-brown, forming loose to rather dense mats. Shoots prostrate or ascending, slender, 240-360 $\mu \mathrm{m}$ wide, up to $6.5 \mathrm{~mm}$ long, often irregularly branched, with postical-intercalary branches, rarely simple. Rhizoids sparse, colourless, in loose fascicles. Stem rounded, 75-90 $\mu \mathrm{m}$ in diameter, cells in cross section rounded-triangular to rounded-polygonal, almost isodiametric, (8-)10-16(-18) $\mu \mathrm{m}$, the cortical cells almost not different in size from medullar ones, more or less equally thickwalled, the internal cells also equally thick-walled or with large triangular to nodulose thickenings (Fig. 3: Q). Leaves almost transversely or often somewhat obliquely inserted, then succubous, antically secund, in dry plants strongly appressed, making the plants filiform or almost vermiform, in moist plants not tightly appressed, erect or erecto-patent or erect-imbricate, with leaf base divergent from the stem but lobe apices oriented towards the stem; (309-)340-370(395) $\mu \mathrm{m}$ wide, (373-)405-440(-464) $\mu \mathrm{m}$ long, usually 1.051.31 times as long as wide, ovate or oblong-ovate, concave, widest in lower 1/3-1/4 of the leaf, occasionally with more or less ampliate leaf base (Fig. 2: I, O, 3: H), bilobed for $(0.15-) 0.18-0.25(-0.29)$ of the length; sinuses acute to rectangular, with concave or convex margins; lobes triangular or ovate-triangular, apiculate or acute, usually ending in two superposed cells, rarely in one cell (Fig. 3: A-I, M, P); the leaf margins normally neither decolorate, nor erose, never reflexed, almost entire in upper 2/3, in lower third sometimes armed with a partial border of radially elongated and slightly protruding, thin- to moderately thick-walled cells (Fig. 3: L, N) or with 1-celled rounded teeth (Fig. 3: K, R). Marginal leaf cells mostly rounded-rectangular or angulate, subquadrate to radially (rarely tangentially) elongated, (7-)8-12(-16) $\mu \mathrm{m}$ wide, (9-) 10-14(-20) $\mu \mathrm{m}$ long, equally thick-walled (Fig. 3: F, P) or with nodulose thickenings (Fig. 3: C-E, I, M); median cells in lobes (6-)10-14(-18) $\mu \mathrm{m}$ wide, (9-)12-18(20) $\mu \mathrm{m}$ long, laminar leaf cells (9-)11-17(-19) $\mu \mathrm{m}$ wide, (12-)14-19(-25) $\mu \mathrm{m}$ long; cell walls with distinct, concave or convex trigones (Fig. 3: Q) or moderately to distinctly 


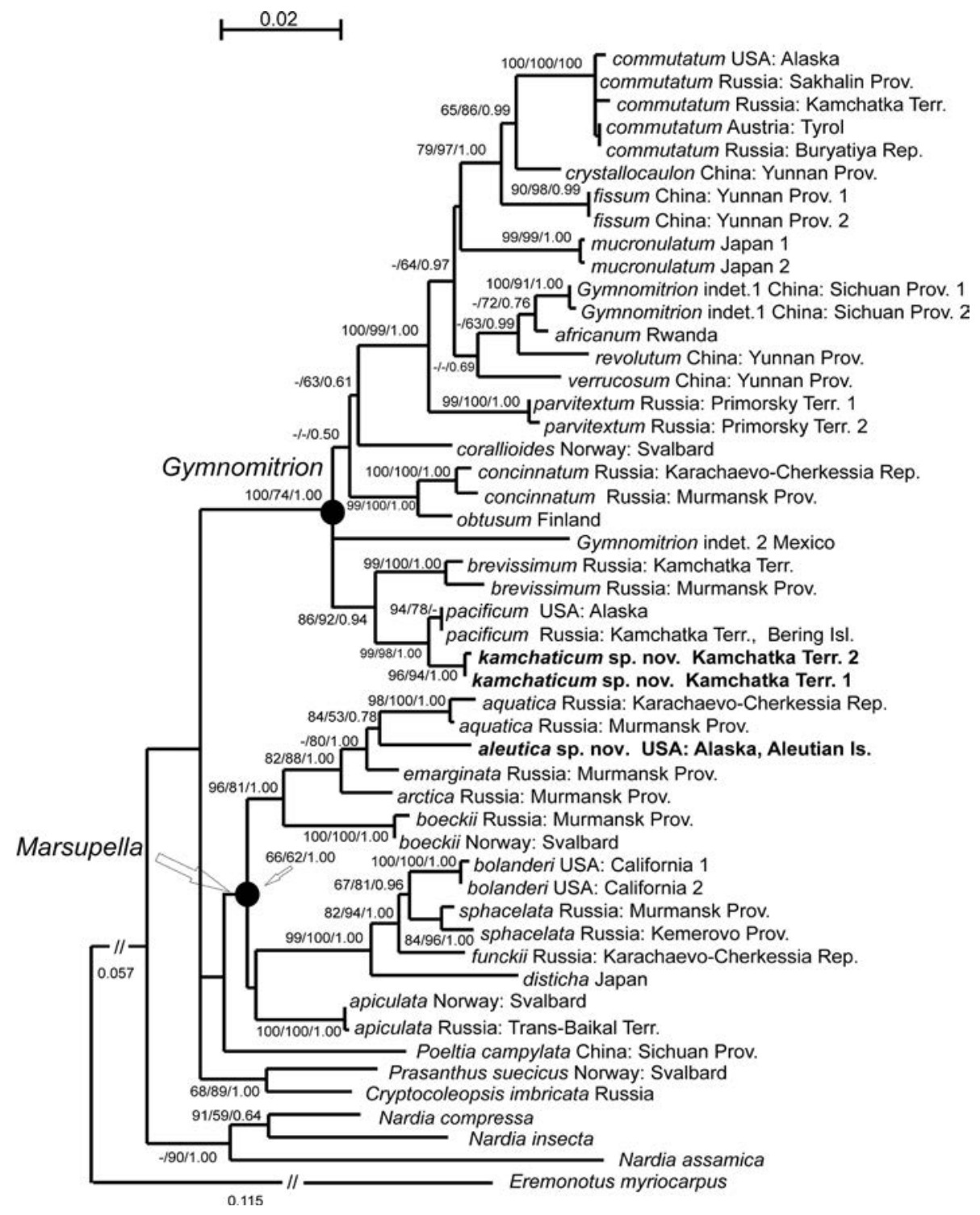

Figure 1 Phylogram obtained in a maximum likelihood calculation for the family Gymnomitriaceae based on combined nucleotide sequences dataset of ITS1-2 nrDNA and trnL-F cpDNA. Bootstrap support values of maximum likelihood and maximum parsimony analyses more than $50 \%$ and Bayesian posterior probabilities more than 0.50 are indicated

(especially in marginal parts) evenly thickened (Fig. 3: F, K, L, $\mathrm{O}, \mathrm{P})$. Cuticle smooth or minutely verruculose. Underleaves absent. Dioecious. Androecia spicate, terminal (Fig. 6: C, E, F) becoming intercalary (Fig. 2: H, J, N). Androecial bracts in 4-10 or more pairs, imbricate, $480-640 \mu \mathrm{m}$ wide, $480-$ $580 \mu \mathrm{m}$ long, as wide as long or somewhat wider than long, rounded-ovate to subrotundate, in lower third often armed at margins with elongated protruding cells and rounded teeth. Antheridia obovate to subglobose, one per bract, stalk biseriate. Gynoecial bracts similar to leaves but much larger and more concave, with apiculate lobes. Otherwise unknown.

Holotypus. RUSSIA. Kamchatka Territory, East Kamchatka, Ganalsky Range, Bakening volcano area, upper course of Pravaya Kamchatka River (53 $56^{\prime} 45^{\prime \prime N}$, $\left.158^{\circ} 01^{\prime} 56^{\prime E} \mathrm{E}\right), 900 \mathrm{~m}$ a.s.l., subalpine belt, on moist boulder in open place, 4 August 2015, leg. V.A. Bakalin, No. K-4419-15 (VBGI, isotypes KPABG, MHA).
Paratypus. RUSSIA. Kamchatka Territory, East Kamchatka, Ganalsky Range, Bakening volcano area, upper course of Pravaya Kamchatka River $\left(53^{\circ} 56^{\prime}\right.$ $\left.27^{\prime \prime} \mathrm{N}, 158^{\circ} 01^{\prime} 31^{\prime \prime E}\right), 900 \mathrm{~m}$ a.s.l., in crevice in gravely barrens in alpine belt, 4 August 2015, leg. V.A. Bakalin, No. K-43-10-15 (KPABG, MHA, VBGI).

Etymology. The epithet 'kamchaticum' comes from the Kamchatka Peninsula where the species was collected.

Distribution and ecology. Gymnomitrion kamchaticum is known from just two collections but it is likely that the species is underrecorded. The habitats in both collecting localities are rocky substrates at the same latitude (the distance between the two localities is less than $500 \mathrm{~m}$ ). Both collections are made from open places with scattered Pinus pumila (Pall.) Regel clumps and hepatics mats of Cryptocolea imbricata R.M. Schust., Gymnomitrion concinnatum (Lightf.) Corda, G. brevissimum, Pseudolophozia debiliformis (R.M. Schust. \& Damsh.) Konstant. \& Vilnet, Preissia quadrata (Scop.) Nees. nearby.

Marsupella aleutica Mamontov, Vilnet, Konstant. et Bakalin sp. nov. Fig. 4, 5, 6: B, D

Description. Plants small, shoots up to $5 \mathrm{~mm}$ long and 500-600 $\mu \mathrm{m}$ wide, in gametangia area up to $700 \mu \mathrm{m}$, pectinate, olive green to yellow brownish, but the specimen is quite old and the color is probably modified. Stems erect, simple or with few lateral-intercalary branches and subfloral innovations. Stolons not seen. Stem $125 \mu \mathrm{m}$ in diameter, cortex of one to two layers of relatively large, hyaline, thin- or thick-walled and slightly tangentially elongated cells $15 \times 17-22(-25) \mu \mathrm{m}$, only slightly smaller and thin-walled innermost cells and cells of the medulla that are mixtures of single small to large cells varying from 10 to $15 \mu \mathrm{m}$ in diameter. Rhizoids few. Leaves distichously arranged, sometimes almost suborbicular and ca. $450 \mu \mathrm{m}$ wide, $450 \mu \mathrm{m}$ long, but often wider than long (ca. 1.14-1.4 as wide as long) and then ca. $400-450 \mu \mathrm{m}$ wide, $320-350$ $\mu \mathrm{m}$ long, inserted transversely to somewhat obliquely, then succubous, patent or erecto-patent, somewhat conduplicate to canaliculate, with fold antically oriented and forming a "concave" habit of shoots, almost equal in size apart from gynoecia slightly larger below, slightly to strongly imbricate especially in the gynoecial area, subequally or often unequally 


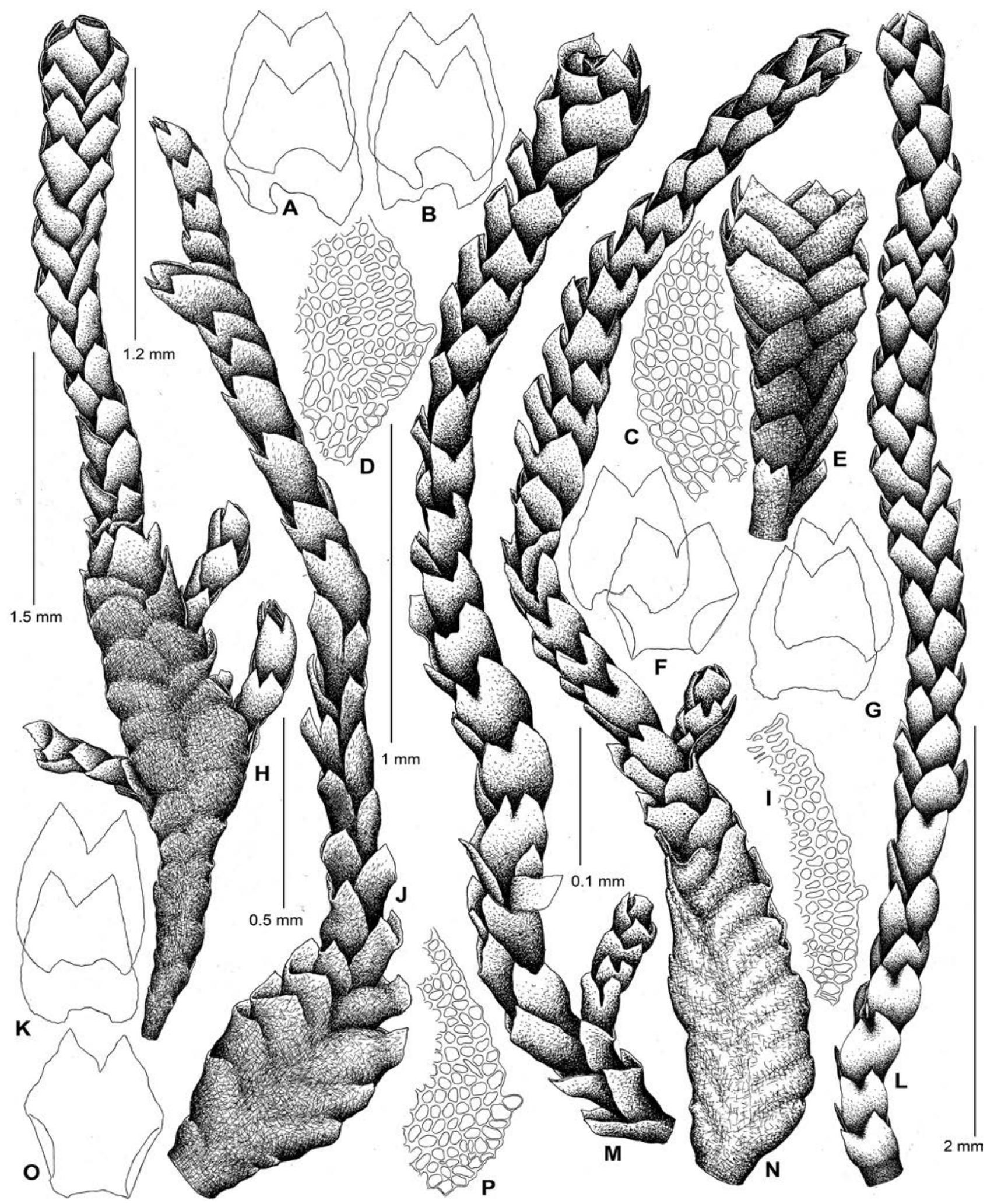

Figure 2 Gymnomitrion kamchaticum Mamontov, Vilnet et Konstant.: A, B, F, G, K, O - leaves; C, D, I, P - leaf margins in the basal third, with cell outlines indicated; $\mathrm{E}$ - female plant, dorsal view; $\mathrm{H}, \mathrm{J}, \mathrm{N}$ - male plants, dorsal view; L, M - sterile plants. Scales: $0.1 \mathrm{~mm}$ for C, D, I, P; 0.5 $\mathrm{mm}$ for $\mathrm{A}, \mathrm{B}, \mathrm{F}, \mathrm{G}, \mathrm{K}, \mathrm{O} ; 1 \mathrm{~mm}$ for $\mathrm{E} ; 1.5 \mathrm{~mm}$ for $\mathrm{H} ; 1.2$ for J and $\mathrm{M} ; 2 \mathrm{~mm}$ for L. All from isotype (MHA)

bilobed, then with larger ventral part, with rounded bases, sometimes with dorsal base (in one to several leaves per shoot) with a lobe-like tooth (Fig. 4: C, D, E, K, M, N, 5: D, $\mathrm{J}$ ), with a more or less conspicuous border of rather equally thick-walled 1-2(-3) rows of marginal cells (Fig. 5: F-L). Sinuses descending for $0.2-0.25$ of leaf length, variable from acute to rounded V-shaped, U-shaped, in some leaves slightly narrowly reflexed at base, lobes broadly triangular, blunt but more often acute, often ending in one or even two celled apiculi, but cells of apiculi are wide, small, ca. 10-13 $\mu \mathrm{m}$ wide, 8-10 $\mu \mathrm{m}$ long. Leaf margins not reflexed. Marginal cells subquadrate, ca. (8-)10-13 $\mu \mathrm{m}$ diagonally, of- 

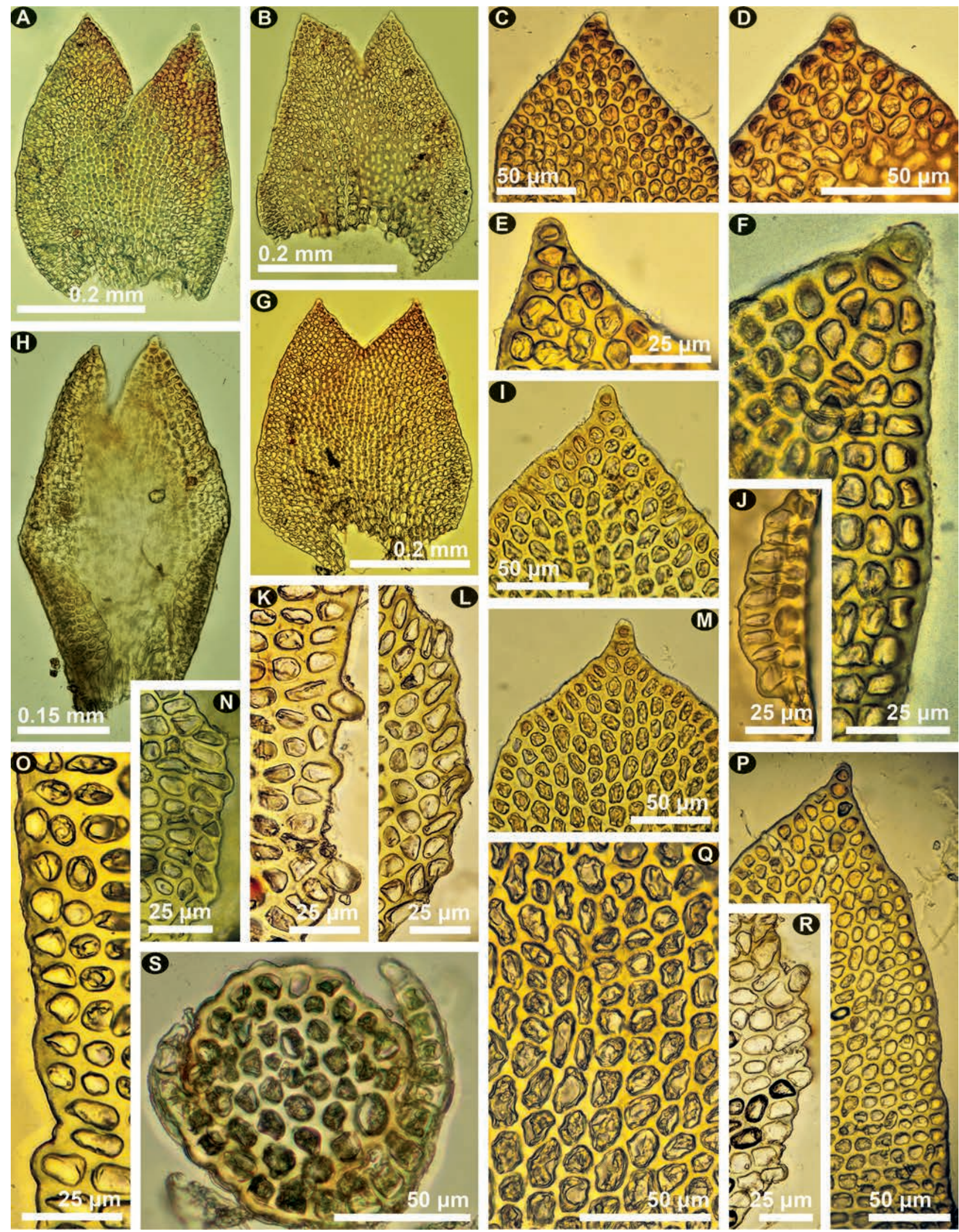

Figure 3 Gymnomitrion kamchaticum Mamontov, Vilnet et Konstant.: A, B, G, H - leaves; C, D, E, F, I, M, P - parts of leaves showing lobe apices and cell outlines; J, K, L, N, R - leaf margins armed with elongated protuberant cells and 1-celled teeth; O - leaf margin showing marginal cell outlines; Q - median leaf cells; $\mathrm{S}$ - stem cross section. All from isotype (MHA)

ten rounded-rectangular, with longest side mostly oriented perpendicular to leaf margin. Midleaf cells with indistinct or rather distinct, concave to convex, sometimes confluent trigones, rounded-hexagonal in shape, small, in lobes 10 $14 \mu \mathrm{m}$ in diameter, in the middle (10-)13-15(-17) $\mu \mathrm{m}$ wide, 15-17(-20) $\mu \mathrm{m}$ long, at base slightly larger and elongated, 


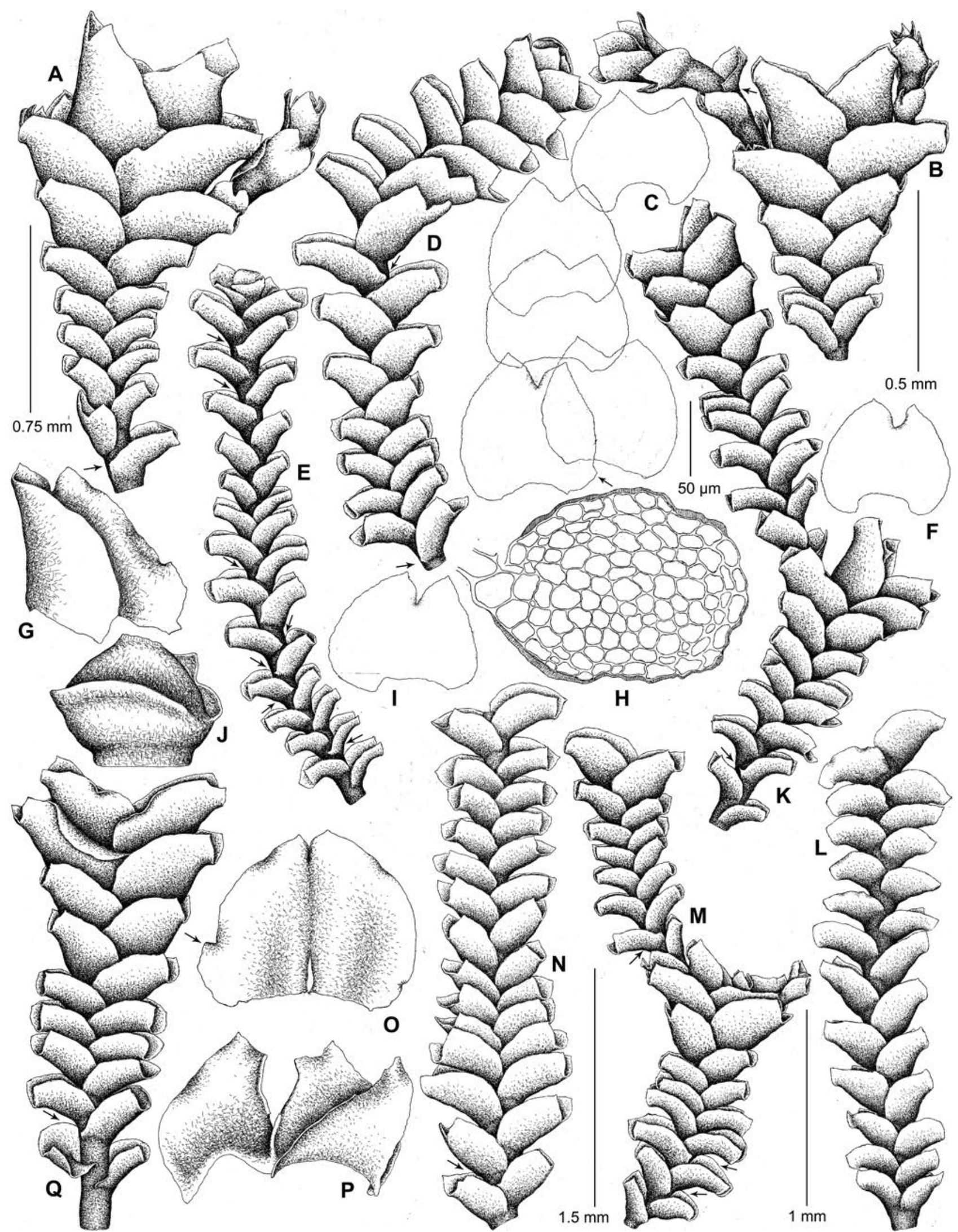

Figure 4 Marsupella aleutica Mamontov, Vilnet, Konstant. et Bakalin: A, B, K, M, Q - female plant, dorsal view; C, F, I - leaves; D, E, N - sterile plants, dorsal view; $\mathrm{G}, \mathrm{O}$ - female bracts; $\mathrm{H}$ - stem cross section; J - juvenile perianth; $\mathrm{L}$ - sterile plant, ventral view; $\mathrm{P}$ - female bract with unfolded juvenile perianth. Arrows point basal teeth in sterile leaves and female bracts. Scales: $50 \mu \mathrm{m}$ for H; $0.5 \mathrm{~mm}$ for C, F, I; $0.75 \mathrm{~mm}$ for $\mathrm{G}, \mathrm{J}, \mathrm{O}, \mathrm{P} ; 1 \mathrm{~mm}$ for $\mathrm{L} ; 1.5 \mathrm{~mm}$ for $\mathrm{K}, \mathrm{M}$. All from isotype (KPABG)

ca. 14-17 $\mu \mathrm{m}$ wide, $17-20(-25) \mu \mathrm{m}$ long; cuticle smooth, oil bodies not seen. Dioecious. Only female plants were found in the studied specimen. Bracts (Fig. 4: G, O, P) from $550 \times$
$550 \mu \mathrm{m}$ to $580-680 \mu \mathrm{m}$ wide and $420-600 \mu \mathrm{m}$ long, as long as wide or $1.28-1.38$ as wide as long, about $0.15-0.2$ bifid, with acute and slightly narrowly reflexed at base sinuses; 

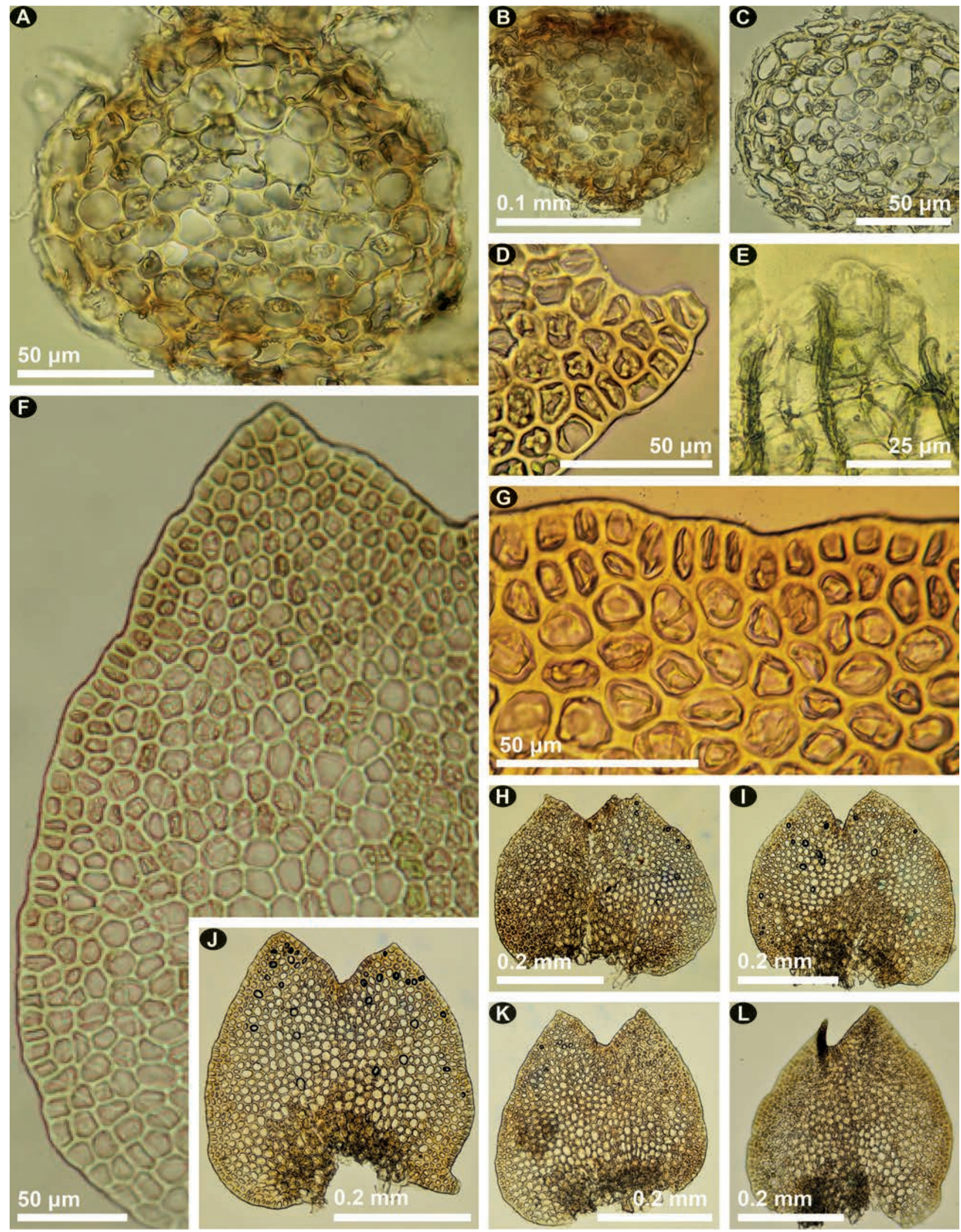

Figure 5 Marsupella aleutica Mamontov, Vilnet, Konstant. et Bakalin: A-C - stem cross sections; D - a lobe-like basal tooth; E - cells of the perianth mouth; F - part of leaf showing lobe apex and cell outlines; $\mathrm{G}$ - marginal leaf cells; $\mathrm{H}-\mathrm{L}$ - leaves. All from isotype (KPABG)

lobes slightly unequal, broadly triangular, acute to subacute or obtuse. Perigynium low in unfertilized plants, juvenile perianth much shorter than bracts (Fig. 4: J, P). Otherwise unknown.
Holotypus. USA. Alaska, Shumagin Islands, Simeonof Island (54 $\left.{ }^{\circ} 55^{\prime} \mathrm{N} 159^{\circ} 15^{\prime} \mathrm{W}\right)$, leg. W.B. Schofield, No. 103958 (UBC, sub Marsupella alpina; isotype KPABG, sub Marsupella alpina). 

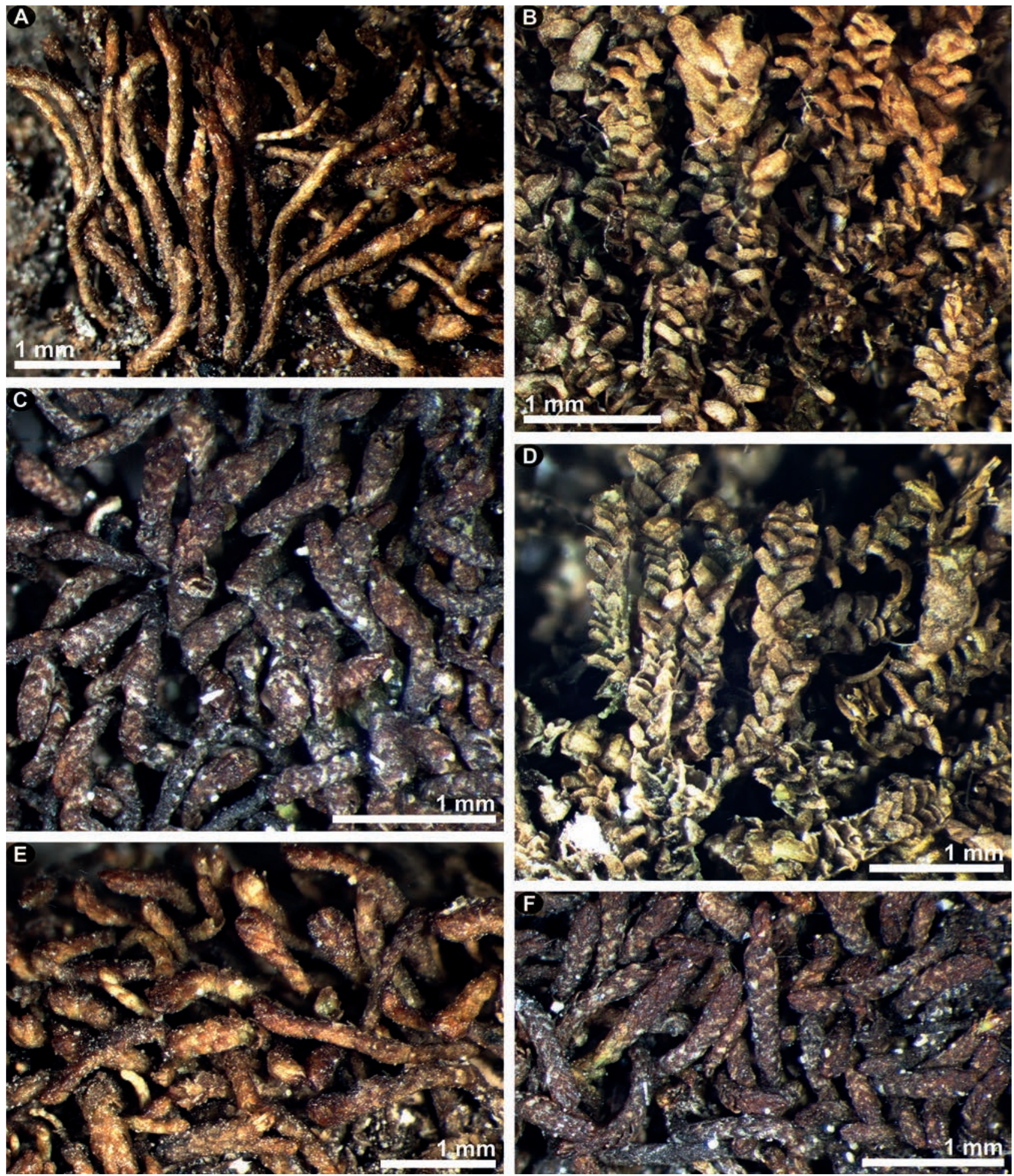

Figure 6 Gymnomitrion kamchaticum Mamontov, Vilnet et Konstant.: A, C, E, F - dry plant habit. A, E from isotype (MHA). C, F from paratype Bakalin K-43-10-15 (MHA). Marsupella aleutica Mamontov, Vilnet, Konstant. et Bakalin: B, D - dry plant habit. All from isotype (KPABG)

Etymology. The epithet 'aleutica' comes from the Aleutian Islands chain (Simeonof Island) where the species was collected.

Distribution and ecology. Currently Marsupella aleutica is known only from the Simeonof Island. According to Schofield et al. (2004) it is "the highly "alpine" species" occurring infrequently "at the higher elevations, where the crowberry heath forms continuous slopes".

\section{DISCUSSION}

\section{Gymnomitrion kamchaticum}

Differentiation. Due to erecto-patent (in moist condition) antically secund leaves and often wholly entire leaf margins, the dioecious specimens of Gymnomitrion kamchaticum were initially identified as Marsupella brevissima (Dumort.) Grolle. The latter species is monoecious, but Damsholt 
(2002) notes that "pure male and female plants perhaps also occurring". It should, however, be noted that sterile plants of the new species differ from Marsupella brevissima (三Gymnomitrion brevissimum) in more trapezoidal shape of leaves, mucronate leaf lobes and sometimes crenulate or toothed margins in lower third of leaves. Among other regional taxa, dry plants of Gymnomitrion kamchaticum are most similar to G. pacificum and G. mucronulatum by its filiform habit, and to G. mucrophorum by mucronate leaf lobe apices. Due to suggested occurrence of pure male and female plants in G. brevissimum, an artificial key is provided to distinguish the sterile plants of the discussed five species:

1. Plants usually chestnut-brown or fuscous black. Leaves distally erect-spreading to erect-imbricate, never tightly appressed, with lobes acute or subacute at apex, normally entire-margined, with marginal $1-2$ cell rows usually persistent, not differentiated from intramarginal cells, not hyaline at maturity, \pm tangentially elongated ........... G. brevissimum

1. Plants whitish, greenish, yellowish to brown, rarely redbrown. Leaves close, frequently tightly appressed, with lobes usually (when not erose) ending by a mucro, with margins serrulate or \pm clearly crenulate over the whole length or near lobe tips or near leaf base, with marginal cells in 1-3-rows usually (at least in part of leaves) variously differentiated, that is, thin-walled and slender, or moderately to strongly thick-walled, often elongated obliquely or at right angles to the margin .

2. Leaf lobes obtuse to almost rounded at apex through erose margins, rarely (in a few leaves) clearly mucronate or apiculate. Leaf margins in upper $2 / 3$ more or less crenulate with a partially erose border of $1-2(-3)$ rows of hyaline cells elongated obliquely or at right angle to the margin, with protuberant free ends

G. pacificum

2. Leaf lobes usually clearly apiculate or mucronate. Leaf margins normally not erose, serrulate at apex, or \pm crenulate over the whole length, or crenulate only in lower third of leaf ....... 3

3. Leaf lobes serrulate with thick-walled, suberect to obliquely somewhat elongate cells whose strongly thick-walled free apices are bluntly to sharply angularly projecting

G. mucrophorum

3. Leaf lobes entire-margined or slightly crenulate, not serrulate; marginal cells with rounded to obliquely elongate and rectangulate lumen, with free ends projecting as rounded crenulations

\section{4}

4. Leaves in both moist and dry shoots very densely imbricate and very closely appressed to each other, markedly transversely inserted, with lobe tips directed to shoot apex; the lobes often asymmetric through inner margins longer than outer margins, thus divaricate with wide angle; the leaf margins slightly (in upper 1/2) to distinctly (in lower $1 / 3-1 / 2$ ) continuously crenulate by roundly projected cells; the marginal cells distinctly smaller than the laminar ones, with a rounded lumen, moderately to strongly equally thickwalled, with the walls often as broad as or broader than the cell lumen; the projected cells almost subisodiametric, with the external walls often strongly thickened ......

G. mucronulatum

4. Leaves in moist shoots erect to nearly patent, not tightly appressed, contiguous or occasionally distant, somewhat obliquely inserted and antically secund; the lobes usually symmetric, often almost triangular and isosceles, divergent with acute to right angle; in upper $2 / 3$ the leaves entire-margined, in lower $1 / 3$ the leaf margins entire or sometimes crenulate with rounded protruding cells or 1 -celled rounded teeth; the marginal cells with a rounded-multiangular or rounded-rectangular lumen, with interior walls slightly to moderately thickened, with concave to convex trigones; in upper $2 / 3$ of leaf the marginal cells similar to the laminar ones in shape and size, in lower $1 / 3$ of leaf the marginal cells partly projected and \pm elongated radially, forming at places partial border

G. kamchaticum

Characteristics of localities. The area where Gymnomitrion kamchaticum was collected occupies an intermediate position between the Central Kamchatka with its subcontinental climate and the easternmost fringes of the peninsula with its oceanic climate (cf. Bakalin \& Klimova 2018). The site is situated in the way of Pacific wet air masses via Avacha River Valley to the Central Kamchatka depression and the only mountain that may intercept some moisture in wet air masses is the Bakening volcano, thus the area near locus classicus. Both localities are in the transitional zone between alpine and subalpine vegetation. Although the dominant bedrocks are relatively acidic andesite (although less acidic than granite) we may suspect the presence of base-rich volcanic ashes that permit such taxa as Peltolepis quadrata (Saut.) Müll. Frib. and Mesoptychia heterocolpos (Thed. ex Hartm.) L. Söderstr. \& Váňa to grow in the crevices near loci classici. These base-rich ash solutions may influence for the habitats where the new taxon was collected.

\section{Marsupella aleutica}

Differentiation. Marsupella aleutica differs from all morphologically similar species by the frequent development of a basal tooth on the dorsal margin of sterile leaves. Such a marker is until now unknown in the Holarctic species of the genus (cf. Kitagawa 1963, Schuster 1974, Paton 1999). The species is similar to $M$. funckii in the leaf orientation, cell size and stem anatomy. It differs from it in color, being olive-green to yellow-brownish vs. deep green to blackish green in $M$. funckii, much shorter sinuses that are not deeper than $0.2-0.25$ of leaf length whereas reaching $0.33-0.45$ in $M$. funckii, even more smaller leaves and cells of margins, thick-walled cells in the middle of leaves, slightly reflexed sinus margin in some leaves, somewhat complicate leaves with uneven lobes, that is not characteristic for $M$. funckii. The species is similar to species of Marsupella sect. Ustulatae Müll. Frib. ex R.M. Schust. in the size, the shape and orientation of leaves, but differs from it in dioicy, different color of plants being green, yellow-green to light brownishgreen versus fuscous to scorched in M. sprucei and $M$. ustulata Spruce, absence of stolons that are usually numerous in sect. Ustulatae, not largely distally leaved shoots that are characteristic for M. sprucei and M. ustulata. According to obtained molecular results $M$. aleutica is closely related to M. emarginata (Ehrh.) Dumort. and M. aquatica, the members of the former complex M. emarginata s.l. (cf. Kitagawa 1963, Schuster 1974, Damsholt 2002), which probably includes also North American M. paroica R.M. Schust. and a number of East Asian taxa - M. emarginata sensu Kitagawa (1963). $M$. alentica agrees with $M$. emarginata s.l. by distichously arranged, conduplicate to canaliculate leaves, but differs in much smaller size, much smaller leaf cells, not reflexed margins of leaves and evenly thick-walled marginal cells, also 
stem anatomy. From $M$. paroica it also differs by dioicy (vs. paroicy). Among the East Asian taxa, M. pseudofunckii and $M$. minutissima are most similar in appearance to the new taxon. M. pseudofunckii has asymmetric leaves with distinctly unequal leaf lobes (Kitagawa 1963), whereas M. aleutica has more or less symmetric leaves with nearly equal lobes. M. minutissima has much longer sinuses, up to 0.33 of leaf length (whereas reaching $0.2-0.25$ in $M$. aleutica), and leaves longer than wide.

To attempt of generalization the differences between the mentioned above morphologically related species, an artificial key is provided below. This key does not contain all the Holarctic Marsupella and leaves some species complexes undivided due to priority of determining $M$. alentica and existing of unresolved taxonomic difficulties in need of special studies.

1. Plants large, with sterile parts of shoots up to $0.5-2.5 \mathrm{~mm}$ wide, not or slightly broadened in the gynoecium area; leaves often \pm reflexed along margins (at least at their bases) ......... 2 1. Plants minute, sterile shoots ca. $300-800 \mu \mathrm{m}$ wide, leaves much smaller to the base of shoot, gradually larger up the stem, fertile shoots with female bracts much larger than leaves, thus somewhat stoutly (occasionally abruptly) clavate; leaves not reflexed along margins ... 5

2. Leaves asymmetric with distinctly unequal lobes .....

\section{M. emarginata subsp. tubulosa var. patens}

2. Leaves usually symmetric, with almost equal lobes ......... 3

3. Leaves not reflexed along margins

.................... M. emarginata subsp. tubulosa var. tubulosa

3. Leaves reflexed along margins, at least on some upper and subinvoluclar leaves ............................................................. 4

4. Paroecious

M. paroica

4. Dioecious

M. aquatica, M. emarginata subsp. emarginata and M. emarginata subsp. tubulosa var. apertifolia

5. Paroecious, almost always fertile; shoots largely distally leaved; leaves moderately to strongly concave, contiguous or weakly imbricate and small near shoot bases, becoming rather closely imbricate and erect-appressed above (especially on fertile shoots), stolons usually numerous ................... sect. Ustulatae (M. sprucei and M. ustulata)

5. Dioecious; shoots not so largely distally leaved; leaves patent or erecto-patent or obliquely spreading, \pm conduplicate to canaliculate; stolons absent or infrequent

6. Leaves asymmetric with distinctly unequal lobes ...

M. pseudofunckii

6. Leaves usually symmetric with almost equal lobes 7

7. Leaf sinus normally not deeper than 0.25 of leaf length, basal tooth on the dorsal margin of sterile leaves occasional or frequent

M. aleutica

7. Leaf sinus normally reaching $0.33-0.45$ of leaf length, basal tooth on the dorsal margin of sterile leaves absent ... 8

8. Leaves longer than wide (ca. 1.14-1.25 as long as wide) ....... M. minutissima

8. Leaves barely wider than long (ca. 1.03-1.13 as wide as long) M. funckii

Notes on distribution. Of three specimens referred by Schofield et al. (2004) to M. alpina (Gottsche ex Husn.) Bernet we studied one collection and described it as $M$. alentica.
The other two collections from Simeonof Island cited by Schofield et al. (2004) should probably also be referred to this species. Schofield et al. (2004) noted that the vegetation of the island was totally destroyed in the course of the last glaciation and was then populated again by wind-blown diaspores starting from $10000 \mathrm{BP}$ or even later. The record of Marsupella aleutica may put this suggestion in doubt if this species is found nowhere else. However, taking both the commonness of habitat where Marsupella aleutica was collected and the absence of the distinct uniqueness of the island by its nature characteristics into account we may expect the occurrence of this new taxon far beyond the Simeonof Island, and, at least, likely may be observed in the nearest Aleutians or even the Alaska and Kamchatka peninsulas. In general the characteristics of the bryophyte flora of Simeonof Island possesses the dominance of both Arctic and Boreal elements with the latter comprising the overwhelming majority, as in most of the Aleutians.

\section{CONCLUSION}

Among the studied taxa, Marsupella aleutica is most closely related by nucleotide sequences to the Holarctic species M. aquatica, M. arctica and M. emarginata. Gymnomitrion kamchaticum was found in a sister relation to $G$. pacificum, which is known from both sides of the Pacific Ocean - from Alaska, British Columbia and Mexico on the one hand, and from Japan and the Russian Far East (Sakhalin Province, the Kamchatka and Chukotka peninsulas) on the other. According to the phylogenetic relations and rarity of both Gymnomitrion kamchaticum and Marsupella aleutica, are possibly the result of recent speciation in the Northern Pacific under the impact of volcanism as was shown in other liverwort genera (cf. Bakalin \& Vilnet 2014). Both species could currently be treated as endemics of Kamchatka Peninsula and Aleutian Islands respectively. Nonetheless, the data on ranges of both species may be extended due to continuation of Gymnomitrion and Marsupella revisions in the North Pacific, including Chukotka, Alaska and the Aleutians.

\section{ACKNOW LEDGEMENTS}

We are grateful to curators of $\mathrm{MO}$ and $\mathrm{UBC}$ for lending the collections of Gymnomitriaceae for our taxonomic study. We are greatly indebted to Dr. A. Potemkin and Dr. E. Urmi for helpful comments and criticism. Dr. T. Katagiri, the curator of NICH herbarium, is kindly thanked for sending the type of Gymnomitrion mucronulatum for comparative investigation. Mr. A. Hagborg is gratefully acknowledged for fruitful consideration and linguistic correction. The work was partially funded by the Russian Foundation for Basic Research (grants 17-04-00018 and 18-04-00594).

\section{LITERATURE CITED}

Bakalin, V.A. \& A.A. Vilnet 2014. Two new species of the liverwort genus Hygrobiella Spruce (Marchantiophyta) described from the North Pacific based on integrative taxonomy. Plant Systematics and Evolution 300(10):2277-2291.

Bakalin, V.A. \& K.G. Klimova 2018. Liverworts of Nalychevo Nature Park. Komarov's Memorial Lectures 65: 29-54. ББакалин В.А., КАимова К.Г. 2018. ФАора печеночников (Нераticaе) природного парка «Налычево» (полу- 
остров Камчатка) // Комаровские чтения. Вып. 65. C. 29-54].

Damsholt, K. 2002. Illustrated flora of Nordic liverworts and hornworts. Nordic Bryological Society, Lund, 837 pp.

Goloboff, P.A. \& S. Catalano 2016. T.N.T. version 1.5, including a full implementation of phylogenetic morphometrics. Cladistics 32:221-238.

Grolle, R. 1966. Die Lebermoose Nepals. In: Khumbu HimalErgebnisse des Forschungsunternehmens Nepal Himalaya, (W. Hellmich, ed.), pp. 262-298, Springer, Berlin, Heidelberg.

Guindon, S., J.F. Dufayard, V. Lefort, M. Anisimova, W. Hordijk \& O. Gascuel 2010. New algorithms and methods to estimate maximum-likelihood phylogenies: Assessing the performance of PhyML 3.0. Systematic Biology 59:307-321.

Hall, T.A. 1999. BioEdit: a user-friendly biological sequence alignment editor and analysis program for Windows 95/98/NT. Nucleic Acids Symposium Series 41:95-98.

Keane, T.M., T.J. Naughton \& J.O. McInerney 2004. ModelGenerator: amino acid and nucleotide substitution model selection. Available from: http://bioinf.may.ie/software/ modelgenerator/. Last accessed 11.09.2014.

Kitagawa, N. 1963. A revision of the family Marsupellaceae of Japan. Journal of the Hattori Botanical Laboratory 26:76-118.

Mamontov, Yu.S., N.A. Konstantinova, A.A. Vilnet, A.D. Potemkin, E.V. Sofronova \& N.S. Gamova 2018. On resurrection of Marsupella parvitexta Steph. (Gymnomitriaceae, Marchantiophyta) as a semi cryptic species of the genus Gymnomitrion. Nova Hedwigia 106(1-2):81-101.

Müller, K. 2005. SeqState. Primer design and sequence statistics for phylogenetic DNA datasets. Applied Bioinformatics 4:65-69.

Paton, J.A. 1999. The liverwort flora of the British Isles. Harley Books, Colchester, 626 pp.

Pattengale, N.D., M. Alipour, O.R.P. Bininda-Emonds, B.M.E. Moret \& A. Stamatakis 2010 . How many bootstrap replicates are necessary? Journal of Computational Biology 17:337-354.

Potemkin, A.D., Yu.S. Mamontov \& N.S. Gamova 2017. Gymnomitrion fissum (Gymnomitriaceae, Marchantiophyta) - a new species with fissured leaf surface from China. Novosti Sistematiki Nizshikh Rastenii 51:274-280.

Rambaut, A \& A.J. Drummond 2007. Tracer v1.4. Available from http://beast.bio.ed.ac.uk/Tracer. Last accessed 30.10.2018.

Ronquist, F, M. Teslenko, P. van der Mark, D.L. Ayres, A. Darling, S. Höhna, B. Larget, L. Liu, M.A. Suchard \& J.P. Hülsenbeck 2012. MrBayes 3.2: Efficient Bayesian phylogenetic inference and model choice across a large model space. Systematic Biology 61:539-542.

Schofield, W. B., S. S. Talbot \& S. L. Talbot 2004. Bryophytes from Simeonof Island in the Shumagin Islands, southwestern Alaska. Journal of the Hattori Botanical Laboratory 95:155-198

Schuster, R.M. 1974. The Hepaticae and Anthocerotae of North America east of the bundredth meridian. Volume III. Columbia University Press, New York, 880 pp.

Schuster, R.M. 1995. On a new species of Gymnomitrion, G. mucrophorum Schust., sp. n. The Bryologist 98(2):242-245.

Shaw B., B. Crandall-Stotler, J. Váňa, R.E. Stotler, M. von Konrat, J.J. Engel, E.C. Davis, D.G. Long, P. Sova \& A.J.
Shaw 2015. Phylogenetic relationships and morphological evolution in a major clade of leafy liverworts (phylum Marchantiophyta, order Jungermanniales): suborder Jungermanniineae. Systematic Botany 40:27-45.

Söderström, L., A. Hagborg, M. von Konrat, S. Bartholomew-Began, D. Bell, L. Briscoe, E. Brown, D.C. Cargill, D.P. Costa, B.J. Crandall-Stotler, E.D. Cooper, G. Dauphin, J.J. Engel, K. Feldberg, D. Glenny, S.R. Gradstein, X. He, J. Heinrichs, J. Hentschel, A.L. Ilkiu-Borges, T. Katagiri, N.A. Konstantinova, J. Larran, D.G. Long, M. Nebel, T. Pôcs, F. Felisa Puche, E. Reiner-Drehwald, M.A.M. Renner, A. Sass-Gyarmati, A. Schâfer-Verwimp, J.G.S. Moragues, R.E. Stotler, P. Sukkharak, B.M. Thiers, J. Uribe, J. Váňa, J.C. Villarreal, M. Wigginton, L. Zhang \& R.-L. Zhu 2016. World checklist of hornworts and liverworts. PhytoKeys 59:1-828.

Stamatakis, A. 2006. RAxML-VI-HPC: Maximum likelihood-based phylogenetic analyses with thousands of taxa and mixed models. Bioinformatics 22:2688-2690.

Taberlet, P., L. Gielly, G. Pautou \& J. Bouvet 1991. Universal primers for amplification of three non-coding regions of chloroplast DNA. Plant Molecular Biology 17:1105-1109.

Tamura, K., D. Peterson, N. Peterson, G. Stecher, M. Nei \& S. Kumar 2011. MEGA 5: Molecular evolutionary genetics analysis using maximum likelihood, evolutionary distance, and maximum parsimony method. Molecular Biology and Evolution 28:2731-2739.

Váňa, J. 1999. Notes on the genus Marsupella s.lat. (Gymnomitriaceae, Hepaticae) 1-10. Infrageneric taxa. Bryobrothera 5:221-229.

Vilnet, A.A., N.A. Konstantinova \& A.V. Troitsky 2007. On molecular phylogeny of Gymnomitriaceae H. Klinggr. (Hepaticae). In: Computational Phylogenetics and molecular systematics "CPMS' 2007". Conference preceedings, (A.S. Antonov, ed.), pp. 27-29, KMK Scientific Press Ltd, Moscow. Vilnet A.A., Konstantinova N.A., Troitsky A.V. 2007. On molecular phylogeny of Gymnomitriaceae H. Klinggr. (Hepaticae) // Вычислительная филогенетика и геносистематика «ВФГС’ 2007». Материалы межАународной конференции / под реА. А.С. Антонова. Москва: Товарищество научных изданий КМК. С. 27-29].

Vilnet, A.A., N.A. Konstantinova \& A.V. Troitsky 2010. Molecular insight on phylogeny and systematics of the Lophoziaceae, Scapaniaceae, Gymnomitriaceae and Jungermanniaceae. Arctoa 19:31-50.

White, T.J., T. Bruns, S. Lee \& J. Taylor 1990. Amplification and direct sequencing of fungal ribosomal RNA genes for phylogenetics. In: PCR protocols: a guide to methods and applications (M.A. Innis, D.H. Gelfand, J.J. Snisky \& T.J. White, eds), pp. 315-322. San Diego.

Yatsentyuk, S.P., N.A. Konstantinova, M.S. Ignatov, J. Hyvönen \& A.V. Troitsky 2004. On phylogeny of Lophoziaceae and related families (Hepaticae, Jungermanniales) based on $\operatorname{trn} \mathrm{L}-\operatorname{trn} \mathrm{F}$ intron-spacer sequences of chloroplast DNA. In: Molecular Systematics of Bryophytes. Monogr. Syst. Bot. 98 (Goffinet, B., V. Hollowell \& R. Magill, eds), pp. 150-167, Missouri Bot. Gard. Press., St. Louis. 
Appendix 1. The list of taxa, specimens vouchers and GenBank accession numbers, accessions obtained in this study are in bold, accessions downloaded from GenBank are in italic, other - from our previous studies.

\begin{tabular}{|c|c|c|c|}
\hline \multirow{2}{*}{ Taxon } & \multirow{2}{*}{ Specimen voucher } & \multicolumn{2}{|c|}{ GenBank accession number } \\
\hline & & ITS1-2 nrDNA & trnL-F cpDNA \\
\hline \multirow{2}{*}{$\begin{array}{l}\text { Cryptocoleopsis imbricata Amakawa } \\
\text { Gymnomitrion africanum (Steph.) } \\
\text { Horik. }\end{array}$} & Russia, V. Bakalin (DUKE) & no data & KJ802098 \\
\hline & Rwanda, T. Pocs, $8210(\mathrm{~F})$ & no data & KF943101 \\
\hline $\begin{array}{l}\text { Gymnomitrion brevissimum (Dumort.) } \\
\text { Warnst. }\end{array}$ & $\begin{array}{l}\text { Russia: Kamchatka Territory, V. Bakalin, HRE (KPABG) } \\
\text { Russia: Murmansk Prov., N. Konstantinova, } 8171 \text { (KPABG) }\end{array}$ & $\begin{array}{l}\text { EU791834 } \\
\text { EU791833 }\end{array}$ & $\begin{array}{l}\text { EU791712 } \\
\text { EU791711 }\end{array}$ \\
\hline \multirow[t]{4}{*}{$\begin{array}{l}\text { Gymnomitrion commutatum (Limpr.) } \\
\text { Schiffn. }\end{array}$} & $\begin{array}{l}\text { Austria: Tyrol, H. Koeckinger, 41502, 15048, Herbarium } \\
\text { Koeckinger H. (KPABG), 2 }\end{array}$ & MF521468 & MF521479 \\
\hline & $\begin{array}{l}\text { Russia: Buryatiya Rep., N. Konstantinova, 83-2-02, } 104502 \\
\text { (KPABG) }\end{array}$ & EU791828 & EU791707 \\
\hline & $\begin{array}{l}\text { Russia: Kamchatka Territory, V. Bakalin, K-57-14-02-VB, } 104231 \\
\text { (KPABG), } 2\end{array}$ & MF521462 & MF521474 \\
\hline & Russia: Sakhalin Prov., V. Bakalin, K-58-30-05, 110149 (VGBI), 1 & EU791827 & EU791706 \\
\hline \multirow[t]{2}{*}{$\begin{array}{l}\text { Gymnomitrion concinnatum (Lightf.) } \\
\text { Corda }\end{array}$} & $\begin{array}{l}\text { USA: Alaska, Aleutians, Schofield, } 39299 \text { (KPABG) } \\
\text { Russia: Karachaevo-Cherkessia Rep., N. Konstantinova, K465a-05, } \\
109696 \text { (KPABG) }\end{array}$ & $\begin{array}{l}\text { MF521465 } \\
\text { EU791831 }\end{array}$ & $\begin{array}{l}\text { MF521477 } \\
\text { EU791710 }\end{array}$ \\
\hline & Russia: Murmansk Prov., N. Konstantinova, 366-00, 8182 (KPABG) & EU791832 & AF519202 \\
\hline \multirow{4}{*}{$\begin{array}{l}\text { Gymnomitrion corallioides Nees } \\
\text { Gymnomitrion crystallocaulon (Grolle) } \\
\text { Vaña, Crand.-Stotl. \& Stotler } \\
\text { Gymnomitrion fissum Mamontov \& } \\
\text { Potemkin }\end{array}$} & Norway: Svalbard, N. Konstantinova, K155-04, 110103 (KPABG) & EU791826 & EU791705 \\
\hline & $\begin{array}{l}\text { China: Yunnan, D. Long \& J. Shevock, } 37244 \text { (MO, sub } \\
\text { Apomarsupella revoluta) }\end{array}$ & MH826403 & MH822628 \\
\hline & $\begin{array}{l}\text { China: Yunnan, D. Long, } 34684 \text { (DUKE, sub Marsupella commutata), } \\
\text {. }\end{array}$ & no data & $\begin{array}{l}\text { KF943106 (as } \\
\text { G. commutatum) }\end{array}$ \\
\hline & China: Yunnan, D. Long, 34872 (MO, sub Marsupella commutata), 2 & MH826404 & MH822629 \\
\hline \multirow[t]{2}{*}{ Gymnomitrion indet. 1} & $\begin{array}{l}\text { China Sichuan Prov., China-43-1-17, Bakalin \& Klimova (VBGI, } \\
\text { KPABG), } 1\end{array}$ & MK084621 & MK073906 \\
\hline & $\begin{array}{l}\text { China Sichuan Prov., China-45-1-17, Bakalin \& Klimova (VBGI, } \\
\text { KPABG), } 2\end{array}$ & MK084622 & MK073907 \\
\hline \multirow{3}{*}{$\begin{array}{l}\text { Gymnomitrion indet. } 2 \\
\text { Gymnomitrion kamchaticum sp. nova }\end{array}$} & Mexico, Yuarez, 245 (MO) & MH826405 & no data \\
\hline & $\begin{array}{l}\text { Russia: Kamchatka Territory, V. Bakalin, K-43-10-15 (VGBI, } \\
\text { KPABG), } 1\end{array}$ & MK084623 & MK073908 \\
\hline & $\begin{array}{l}\text { Russia: Kamchatka Territory, V. Bakalin, K-44-19-15 (VGBI, } \\
\text { KPABG), } 2\end{array}$ & MH826407 & MH822631 \\
\hline \multirow{2}{*}{$\begin{array}{l}\text { Gymnomition mucronulatum (N. Kitag.) } \\
\text { N. Kitag. }\end{array}$} & Japan, V. Bakalin, J-86-5-15 (VBGI), 1 & & \\
\hline & Japan, V. Bakalin, J-90-9-15 (VBGI), 2 & MK084620 & \\
\hline Gymnomitrion obtusum Lindb. & Finland, Parnela, H4224851 (dupla in KPABG) & MH826406 & MH822630 \\
\hline \multirow[t]{2}{*}{ Gymnomitrion pacificum Grolle } & $\begin{array}{l}\text { Russia: Kamchatka Territory, ,Bering I., V. Bakalin, K-26-4-02-VB, } \\
103350 \text { (KPABG) }\end{array}$ & EU791835 & EU791713 \\
\hline & USA: Alaska, B. Shaw F956/3 (DUKE) & no data & KF943050 \\
\hline \multirow{2}{*}{$\begin{array}{l}\text { Gymnomitrion parvitextum (Steph.) } \\
\text { Mamontov, Konstant. \& Potemkin }\end{array}$} & $\begin{array}{l}\text { Russia: Primorsky Territory, Yu. Mamontov, YuSM 182-1-10 } \\
\text { (KPABG), }\end{array}$ & MF521471 & MF521481 \\
\hline & $\begin{array}{l}\text { Russia: Primorsky Territory, Yu. Mamontov, YuSM 170-1-10 } \\
\text { (KPABG), } 2\end{array}$ & MF521472 & MF521482 \\
\hline \multirow{6}{*}{$\begin{array}{l}\text { Gymnomitrion revolutum (Ne } \\
\text { H. Philib. } \\
\text { Gymnomitrion verrucosum } \\
\text { W.E. Nicholson } \\
\text { Eremonotus myriocarpus (Car } \\
\text { Pearson } \\
\text { Marsupella aleutica sp. nova } \\
\text { Marsupella apiculata Schiffn }\end{array}$} & China: Yunnan Prov., B. Shaw, 5764 (DUKE) & no data & KF943024 \\
\hline & China: Yunnan Prov., D. Long \& J. Shevock, 37182 (DUKE) & no data & KJ802102 \\
\hline & $\begin{array}{l}\text { Russia: Karachaevo-Cherkesia Rep., Konstantinova, K 446-6-05 } \\
\text { (KPABG) }\end{array}$ & EU791839 & EU791716 \\
\hline & USA: Alaska, Aleutian Is, Schofield, 103958 (UBC) & MH826408 & MH822632 \\
\hline & Norway: Svalbard, N. Konstantinova, K93-1-06 (KPABG) & EU791819 & EU791699 \\
\hline & $\begin{array}{l}\text { Russia: Trans-Baikal Territory, V. Bakalin, 5-13-00, } 101464 \\
\text { (KPABG) }\end{array}$ & EU791818 & EU791698 \\
\hline \multirow[t]{2}{*}{$\begin{array}{l}\text { Marsupella aquatica (Lindenb.) } \\
\text { Schiffn. }\end{array}$} & $\begin{array}{l}\text { Russia: Karachaevo-Cherkessia Rep., N. Konstantinova, K517-4-05, } \\
109808 \text { (KPABG) }\end{array}$ & EU791814 & EU791694 \\
\hline & $\begin{array}{l}\text { Russia: Murmansk Prov., N. Konstantinova, 152-5-87, } 6090 \\
\text { (KPABG) }\end{array}$ & EU791813 & AF519201 \\
\hline \multirow{2}{*}{$\begin{array}{l}\text { Marsupella arctica (Berggr.) Bryhn. } \\
\text { \& Kaal. } \\
\text { Marsupella boeckii (Austin) Lindb. ex } \\
\text { Kaal. }\end{array}$} & Norway: Svalbard, N. Konstantinova, 128-04 (KPABG) & EU791815 & EU791695 \\
\hline & $\begin{array}{l}\text { Norway: Svalbard, N. Konstantinova, K93-2a-06 (KPABG) } \\
\text { Russia: Murmansk Prov., N. Konstantinova, 367-2-00, } 8184 \\
\text { (KPABG) }\end{array}$ & $\begin{array}{l}\text { EU791817 } \\
\text { EU791816 }\end{array}$ & $\begin{array}{l}\text { EU791697 } \\
\text { EU791696 }\end{array}$ \\
\hline Marsupella bolanderi (Austin) Underw. & $\begin{array}{l}\text { USA: California, Monterey CO (KPABG), } 1 \\
\text { USA: California, Santa Yen Mts. St. Barbara, } 38802 \text { (KPABG }\end{array}$ & $\begin{array}{l}\text { MF521464 } \\
\text { MF521463 }\end{array}$ & $\begin{array}{l}\text { MF521476 } \\
\text { MF521475 }\end{array}$ \\
\hline Marsupella disticha Steph. & $\begin{array}{l}\text { Japan, Deguchi \& Yamaguchi, Bryophytes of Asia \#170 (2000) } \\
\text { (KPABG) }\end{array}$ & EU791824 & EU791703 \\
\hline \multirow{4}{*}{$\begin{array}{l}\text { Marsupella emarginata (Ehrh.) } \\
\text { Dumort. } \\
\text { Marsupella funckii (F. Weber \& } \\
\text { D. Mohr.) Dumort. } \\
\text { Marsupella sphacelata (Giesecke ex } \\
\text { Lindenb.) Dumort. }\end{array}$} & $\begin{array}{l}\text { Russia: Murmansk Prov., N. Konstantinova, 354-4-00, } 8070 \\
\text { (KPABG) }\end{array}$ & EU791812 & EU791693 \\
\hline & $\begin{array}{l}\text { Russia: Karachaevo-Cherkessia Rep., N. Konstantinova, K516-1-05, } \\
109804 \text { (KPABG) }\end{array}$ & & EU791700 \\
\hline & Russia: Kemerovo Prov., N. Konstantinova, 65/1-00 (KPABG) & EU791821 & AF519200 \\
\hline & $\begin{array}{l}\text { Russia: Murmansk Prov., N. Konstantinova, 25-1-03, } 11225 \\
\text { (KPAB), } 1\end{array}$ & MF521473 & \\
\hline \multirow{2}{*}{$\begin{array}{l}\text { Nardia assamica (Mitt.) Amak. } \\
\text { Nardia compressa (Hook.) Grav }\end{array}$} & Russia: Sakhalin Prov., V. Bakalin, K 54-1a-05 (KPABG) & EU791838 & EU791715 \\
\hline & Canada, Konstantinova, A97/1-95 (KPABG) & EU791837 & AF519188 \\
\hline \multirow{2}{*}{$\begin{array}{l}\text { Nardia insecta Lindb. } \\
\text { Poeltia campylata Grolle }\end{array}$} & Belgium, Konstantinova, 102077 (KPABG) & EU791836 & EU791714 \\
\hline & China: Sichuan Prov., Bakalin, China-48-2-17, 37210 (VGBI) & MH580596 & MH580593 \\
\hline Prasanthus suecicus (Gottsche) Lindb. & Norway: Svalbard, Konstantinova K 121-5-06 (KPABG) & EU791825 & EU791704 \\
\hline
\end{tabular}

